\title{
Alternatywny model finansowania w polskim rolnictwie na przykładzie zagranicznych wzorców
}

\author{
Marta Baraniak*
}

\section{Wstęp}

Rozwój działalności jest uwarunkowany dostępem do kapitału, a działalność rolnicza nie jest w tym zakresie wyjątkiem. Nowoczesna technologia i innowacyjne parki maszynowe, konieczne do utrzymania konkurencyjnej pozycji przy jednoczesnym wzroście produktywności, wymagają ogromnych nakładów kapitałowych. W polskiej literaturze przedmiotu wielokrotnie poruszano już kwestię źródeł finansowania dostępnych w sektorze rolnym (Horbowiec i in. 2016; Felczak 2015; Zawadzka i Szafraniec-Siluta 2014; Kałuża i Krakowska 2013; Marcysiak i Marcysiak 2009). Dzięki wymienionym pracom wiadomo, w jaki sposób rolnicy najchętniej finansują swoją działalność. Członkostwo w Unii Europejskiej zagwarantowało dodatkowe finansowanie, które po upływie ponad 16 lat od przystąpienia do Unii stało się dla rolników podstawowym źródłem kapitału. Należy jednak pamiętać, że wysokość funduszy przeznaczanych na Wspólną Politykę Rolną (WPR) zmienia się z każdą siedmioletnią perspektywą finansowania, a od 2021 r. zmniejszą się one o około 25\% (dotyczy to drugiego filaru WPR). Mając na uwadze nadchodzące zmiany, zarządzający gospodarstwami rolnymi powinni poszukiwać alternatywnych form finansowania, aby utrzymać dotychczasową wydajność podmiotu rolnego. Również instytucje finansowe powinny być przygotowane na przyszłe zapotrzebowanie na kapitał w sektorze rolnym.

Niniejszy artykuł zawiera diagnozę preferencji finansowania działalności innowacyjnej gospodarstw rolnych, a jego celem jest przedstawienie propozycji alternatywnego finansowania gospodarstw rolnych na podstawie modeli stosowanych w państwach poza UE. Preferencje polskich rolników co do finansowania działalności określono w wyniku wywiadów kwestionariuszowych

* Marta Baraniak - doktor, Uniwersytet Łódzki, Wydział Zarządzania, Katedra Zarządzania Finansami Przedsiębiorstwa, marta.baraniak@uni.lodz.pl. 
przeprowadzonych w 2018 r. w województwie łódzkim, a zestawienie przykładowych modeli finansowania powstało na podstawie przeglądu literatury zagranicznej. Autorka przedstawiła rzadko omawiany w polskiej literaturze model finansowania łańcucha wartości w rolnictwie.

\section{Finansowanie gospodarstw rolnych}

Badania nad działalnością innowacyjną wzbudzają w nauce wiele dyskusji. Podstawową przyczyną jest brak skonkretyzowanej terminologii, która pozwalałaby na zero-jedynkowe określenie, czy dany przedmiot bądź usługa są innowacją, czy nie. Nie ulega wątpliwości, że pojęcia wskazane przez OECD pozostawiają duże pole do interpretacji. Dodatkowych trudności przysparza kwestia prowadzenia badań w rolnictwie - uczestnicy tego sektora niechętnie udostępniają informacje na temat działalności swoich podmiotów, a w dodatku, w porównaniu z przedstawicielami pozostałych sektorów gospodarki, są bardzo słabo zinformatyzowani. Są to zapewne podstawowe przyczyny braku większej ilości danych w literaturze na temat finansowania innowacyjnej działalności gospodarstw rolnych (m.in. Kiełbasa i Puchała 2015; Kałuża i Ginter 2014; Kałuża i Krakowska; Kałuża i Rytel 2010).

Przegląd dostępnej literatury przedmiotu pozwala na sformułowanie wniosku o trzech podstawowych formach finansowania tego typu działalności; są to: środki własne (dochody), fundusze europejskie i kredyty bankowe. Dochody w podmiotach rolnych są nadwyżką ekonomiczną, z której rolnik pokrywa nie tylko koszty związane z podstawową działalnością rolniczą, działalnością inwestycyjną czy innowacyjną, lecz również wydatki związane z gospodarstwem domowym. Specyfika branży sprawia, że wiele czynników może determinować wielkość dochodów podmiotu rolnego: powierzchnia gruntów, dopłaty do działalności operacyjnej, towarowość, wartość oraz wydajność produkcji (Średzińska 2017, s. 313), czynnik kapitału oraz praca ludzka (Niezgoda 2009, s. 162-163).

Kredyty bankowe są podstawową dłużną formą finansowania gospodarstw rolnych. Nie każdy bank ma w swojej ofercie produkty przeznaczone dla sektora agro, jednak doskonale wyspecjalizowały się w tym zakresie banki spółdzielcze (Węcławski 2010). Problem podmiotów rolnych jako klientów banków komercyjnych wynika z sezonowości produkcji, która wydłuża czas oczekiwania na zwrot zainwestowanego kapitału, stąd oferta kredytów subsydiowanych, będących formą interwencjonizmu państwowego w rolnictwie (Kata 2011, s. 118). Ten rodzaj wsparcia wzbudza oburzenie części społeczeństwa, która traktuje subsydia jako nieuczciwe działanie względem przedsiębiorczości i konkurencyjności (Góral 2016, s. 60). 
Przystąpienie Polski do Unii Europejskiej według wielu odmieniło oblicze polskiej wsi, co jest zasługą WPR i funduszy europejskich. Nie ulega wątpliwości, że dotacje pobudziły rozwój polskiego rolnictwa, a wielu podmiotom rolnym pozwoliły na unowocześnienie przestarzałego parku maszynowego. W ramach WPR rolnicy mają możliwość corocznego wnioskowania o dopłaty bezpośrednie, których nadrzędnym celem jest wsparcie dochodów rolniczych (MRiRW 2020). Finansowanie rozwoju obszarów wiejskich zapewnia drugi filar WPR, w którym rolnicy mogą ubiegać się o wsparcie działalności inwestycyjnej i innowacyjnej ze środków PROW.

\section{Metodyka badania}

Preferencje rolników w zakresie finansowania działalności innowacyjnej zostały ocenione na podstawie wyników wywiadów kwestionariuszowych przeprowadzonych techniką PAPI na próbie 150 indywidualnych gospodarstw rolnych działających na terenie województwa łódzkiego. Badane podmioty zostały wytypowane przez Instytut Ekonomiki Rolnictwa i Gospodarki Żywnościowej - Państwowy Instytut Badawczy (IEGiGŻ-PIB) z grupy gospodarstw dobrowolnie należących do systemu Farm Accountancy Data Network (polski FADN). Wywiady kwestionariuszowe zostały przeprowadzone przez doradców z Łódzkiego Ośrodka Doradztwa Rolniczego w Bratoszewicach ze względu na prawne ograniczenia dostępu do danych oraz bezpieczeństwo informacji.

Do opracowania wyników wywiadów kwestionariuszowych wykorzystano programy komputerowe - PS Imago 5.1, a także pakiet Microsoft Office (ze szczególnym uwzględnieniem programów Word i Excel).

Proponowany alternatywny model finansowania działalności innowacyjnej powstał na podstawie przeglądu zagranicznej literatury przedmiotu.

\section{Preferencje polskich rolników w zakresie finansowania}

W wywiadach kwestionariuszowych wzięło udział 150 rolników. Do analiz wykorzystano odpowiedzi 149 ankietowanych, ponieważ jeden z respondentów nie odpowiedział na pytanie dotyczące typu prowadzonej działalności. Szczegółową strukturę próby według typu prowadzonej działalności przedstawiono w Tabeli 1 . Najliczniejszą grupę w analizowanej próbie $(46,3 \%)$ tworzyły podmioty prowadzące mieszaną działalność rolniczą, łączącą w różnych proporcjach działalność roślinną i zwierzęcą. Niemal $21 \%$ ankietowanych prowadziło wyłącznie działalność roślinną, a niecałe 33\% - zwierzęcą. 
Tabela 1. Struktura indywidualnych gospodarstw rolnych według typu działalności gospodarstwa $(\mathrm{w} \%)$

\begin{tabular}{|l|c|c|c|c|}
\hline \multirow{2}{*}{ Struktura } & \multicolumn{3}{|c|}{ Typ dzialalności gospodarstwa } & \multirow{2}{*}{ Ogólem } \\
\cline { 2 - 5 } & roślinne & zwierzęce & mieszane & \\
\hline$n$ & 31 & 49 & 69 & 149 \\
\hline$\%$ & 20,8 & 32,9 & 46,3 & 100,0 \\
\hline
\end{tabular}

Źródło: opracowanie własne.

Rolnicy, którzy zadeklarowali wprowadzenie przynajmniej jednej innowacji w latach 2016-2018, zostali zapytani o sposób jej finansowania. Niemal każdy ankietowany, niezależnie od typu prowadzonej działalności, wykorzystał w tym celu środki własne, czyli dochody wypracowane w gospodarstwie rolnym (por. Wykres 1). Odpowiedzi te potwierdzają wnioski płynące z literatury przedmiotu, zgodnie z którymi dochody są najbezpieczniejszym i najczęściej wykorzystywanym źródłem finansowania działalności w gospodarstwach rolnych. Są one doskonałym rozwiązaniem dla sektora rolnego, w którym zarządzający charakteryzują się silną awersją do ryzyka, a ponadto nie wymagają sporządzania dokumentacji ani dodatkowych wizyt w instytucjach finansowych. Przywiązanie do dochodów jest tak silne, że rolnicy często przekładają planowane inwestycje, aby zgromadzić odpowiednie środki i uniknąć zaciągania dodatkowego zobowiązania.

Drugim najczęściej wybieranym źródłem kapitału są fundusze unijne. W kwestionariuszu wywiadu dotacje z PROW zostały oddzielone od dopłat bezpośrednich, które rolnicy otrzymują co roku na podstawie złożonego wniosku. W przypadku działalności roślinnej i zwierzęcej poziom wykorzystania tych dwóch form unijnego dofinansowania jest porównywalny. Podmioty mieszane chętniej korzystają jednak z dotacji PROW niż z dopłat bezpośrednich w celu finansowania działalności innowacyjnej. Z wywiadów nie wynikało, co jest przyczyną tej sytuacji, ale można się domyślać, że złożona formy działalności jest znacznie bardziej kosztochłonna niż dwie pozostałe, dlatego też prawdopodobnie dopłaty bezpośrednie są wykorzystywane raczej na bieżącą działalność, a nie na działalność innowacyjną.

Trzecią wskazywaną przez respondentów formą finansowania są kredyty. Zainteresowanie tym źródłem kapitału jest jednak niemal o połowę niższe niż funduszami europejskimi. Należy też zwrócić uwagę na udział kredytów spółdzielczych - jest on obecnie porównywalny z udziałem kredytów udzielanych przez banki komercyjne. Rola banków spółdzielczych, które od początku istnienia są ściśle związane z sektorem rolnym, powoli się zmniejsza. Rolnicy, zwłaszcza młodzi, coraz częściej korzystają z usług konkurencji, która oferuje nie tylko instrumenty przeznaczone dla tego sektora, lecz również nowoczesne narzędzia obsługi bankowej. 
Poza podstawowymi typami źródeł finansowania wyodrębniono instrumenty alternatywne, do których należy m.in. coraz chętniej wykorzystywane przez rolników finansowanie fabryczne. Niemal $25 \%$ respondentów prowadzących działalność mieszaną skorzystało z takiej formy finansowania, aby wdrożyć innowacje. Znacznie rzadziej wykorzystywane są dobrze znany leasing, przez ponad 9\% rolników prowadzących działalnością roślinną, czy mniej popularna pożyczka leasingowa (łącznie ponad 9\%).

Wykres 1. Źródła finansowania działalności innowacyjnej indywidualnych gospodarstw rolnych według typu prowadzonej działalności (w \%)

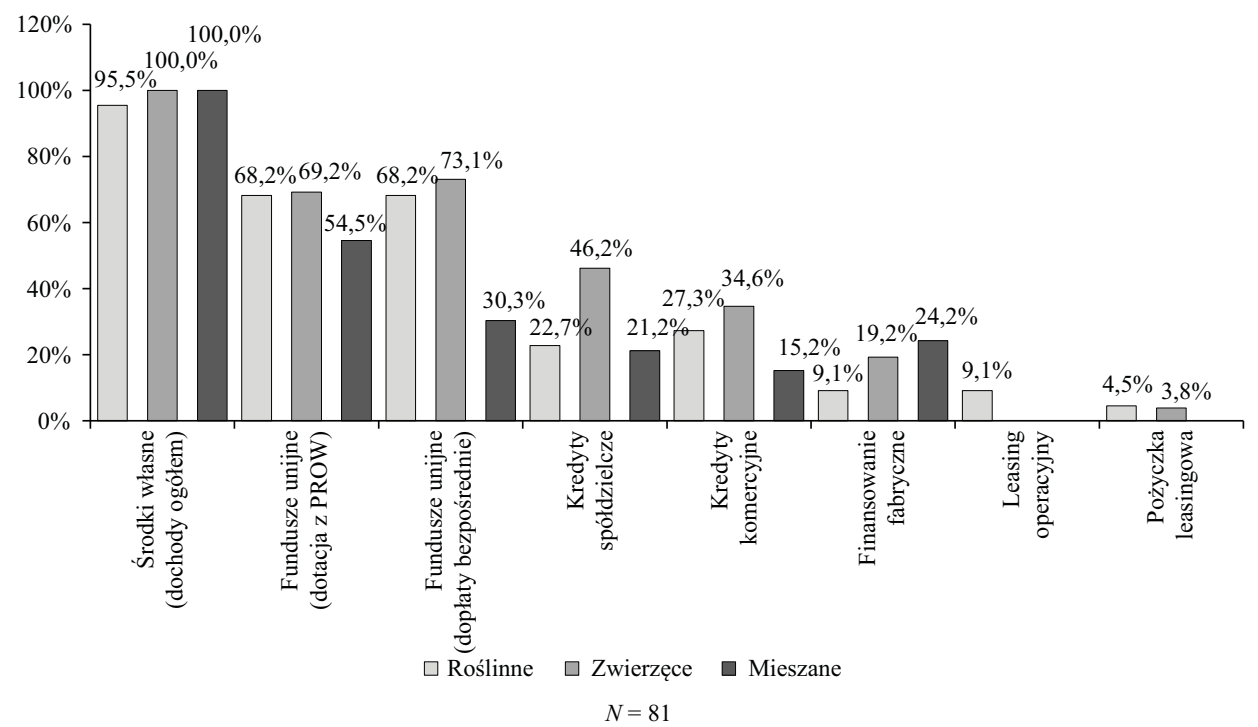

Uwaga: odpowiedzi nie sumują się do $100 \%$, ponieważ respondenci mogli wskazać więcej niż jedną opcję.

Źródło: opracowanie własne.

Wszyscy ankietowani rolnicy, innowacyjni i nieinnowacyjni, zostali również zapytani o przeszkody w pozyskiwaniu konkretnych rodzajów finansowania. W tej kwestii rolnicy również byli zgodni i niemal wszyscy za podstawową przeszkodę uznali ryzyko w rolnictwie, w tym zmienne warunki atmosferyczne, szkodniki i choroby czy fluktuację cen produktów rolnych (por. Wykres 2). Istotnym utrudnieniem, na który wskazało około $70-80 \%$ ankietowanych, jest biurokracja - zbyt szczegółowa dokumentacja może zniechęcić rolników do podejmowania jakichkolwiek działań inwestycyjnych czy innowacyjnych. Nie bez znaczenia pozostaje również typowa dla tego sektora sezonowość produkcji, szczególnie dotkliwa dla $68 \%$ podmiotów roślinnych i $51 \%$ zwierzęcych. Rolnicy dostrzegają też inne utrudnienia: ograniczoną zdolność kredytową, niskie wykształcenie czy 
brak dostępu do informacji, jednak pojawiają się one w odpowiedziach znacznie rzadziej niż te wymienione wcześniej - jedynie w 5-20\% przypadków, w zależności od rodzaju działalności.

Wykres 2. Utrudnienia w finansowaniu indywidualnych gospodarstw rolnych według typu prowadzonej działalności (w \%)

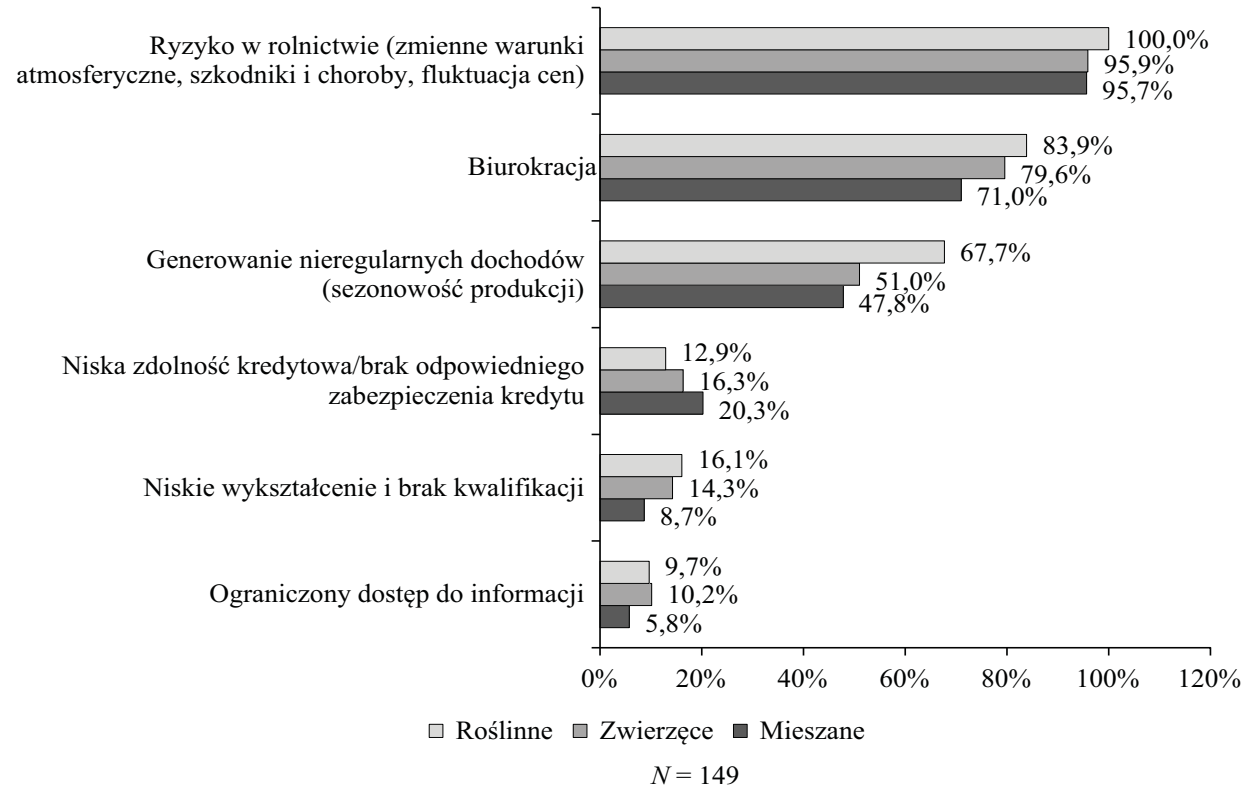

Uwaga: odpowiedzi nie sumują się do $100 \%$, ponieważ respondenci mogli wskazać więcej niż jedną opcję.

Źródło: opracowanie własne.

Omówione źródła finansowania oraz problemy związane z ich pozyskiwaniem są doskonałym wstępem do rozważań o instrumentach finansowych przeznaczonych dla sektora rolnego. Po przeanalizowaniu danych nasuwa się pytanie: czy produkty oferowane przez polski rynek finansowy są dla sektora wystarczające? A może niektóre wymagają korekty? Rolnicy, silnie przywiązani do tradycyjnej formy finansowania $z$ własnych środków, mogą niechętnie sięgać po innowacje finansowe. Jednak $z$ drugiej strony podmiotami rolnymi zaczyna zarządzać młode pokolenie, dla którego liczy się szybkość pozyskania środków, a dochody i fundusze europejskie mogą nie spełniać jego oczekiwań w tym zakresie. Autorka postanowiła zatem zaproponować pewien model finansowania nazywany finansami łańcucha wartości, który stosowany jest w państwach poza UE. Model ten, przynajmniej częściowo, może sprawdzić się jako forma finansowania działalności polskich gospodarstw rolnych. 


\section{Finanse łańcucha wartości}

\section{Istota modelu finansowania}

W kontekście licznych utrudnień w finansowaniu polskiego rolnictwa idealnym modelem mogą okazać się finanse łańcucha wartości (ang. value chain finance - VCF), powszechnie stosowane w krajach Ameryki Łacińskiej, w Azji, Afryce i częściowo w Europie. VCF polega na przepływie środków pomiędzy poszczególnymi ogniwami fizycznego łańcucha dostaw (Rysunek 1). Innymi słowy są to usługi i produkty finansowe pochodzące $\mathrm{z}$ łańcucha wartości i/lub oferowane za jego pośrednictwem w celu zaspokojenia potrzeb podmiotów zaangażowanych w ten łańcuch (Miller i Jones 2010, s. 2). W VCF przepływ finansowy jest odwrotny do fizycznego przemieszczenia towarów i może przybierać formę pożyczki, zaliczki, akredytywy, ubezpieczenia lub innych instrumentów finansowych (Zawojska 2008, s. 102-103). Finanse łańcucha wartości zapewniają bezpieczeństwo sprzedaży i pozyskiwania produktów oraz redukują ryzyko i/lub poprawiają efektywność w ramach łańcucha (GPFI 2015, s. 17). W VCF podaż instrumentów następuje nie tylko ze strony instytucji finansowych, lecz również wzdłuż samego łańcucha dostaw, co przedstawiono na Rysunku 1. Wyróżnia się następujące rodzaje finansów łańcucha wartości (Miller i Jones 2010, s. 2):

- wewnętrzne (ang. internal value chain finance) - tworzą się w ramach łańcucha wartości, np. gdy dostawca wewnętrzny udziela kredytu rolnikowi lub gdy firma prowadząca przekazuje fundusze pośrednikowi rynkowemu (ang. market intermediary);

- zewnętrzne (ang. external value chain finance) - powstają w wyniku powiązań i mechanizmów w łańcuchu wartości, np.: bank udziela pożyczki rolnikowi na podstawie umowy/kontraktu z zaufanym nabywcą lub kwitu magazynowego z zaufanego magazynu.

VCF jest zatem doskonałym sposobem finansowania nie tylko działalności bieżącej, lecz również działalności innowacyjnej w ramach modelu interakcyjnego, tworzonego przez wiele różnych podmiotów o określonych funkcjach. Finansowanie łańcucha wartości w takim przypadku obejmowałoby zatem m.in. gospodarstwa rolne, instytuty badawcze, brokerów, ośrodki doradztwa rolniczego, instytucje finansowe, handlowców, firmy i branże związane z rolnictwem.

Finansowanie łańcucha wartości to szerokie ujęcie finansów rolnictwa, bazujące nie tylko na instrumentach finansowania, lecz również na produktach ograniczających ryzyko i wspierających podstawowe usługi finansowe. VCF można zatem określić jako „kompletny pakiet” wsparcia finansowego rolnictwa. Duża dywersyfikacja dostępnych instrumentów w łańcuchu wartości umożliwia ich dobór w zależności od potrzeb transakcyjnych i charakteru uczestniczącego w transakcji podmiotu. W tabeli 2 przedstawiono instrumenty finansowe wykorzystywane w łańcuchu wartości według klasyfikacji Calvina Millera i Linde Jones. 
Rysunek 1. Schemat finansowania łańcucha wartości

\begin{tabular}{|c|}
\hline Podaż usług \\
finansowych \\
Instytucje finansowe
\end{tabular}

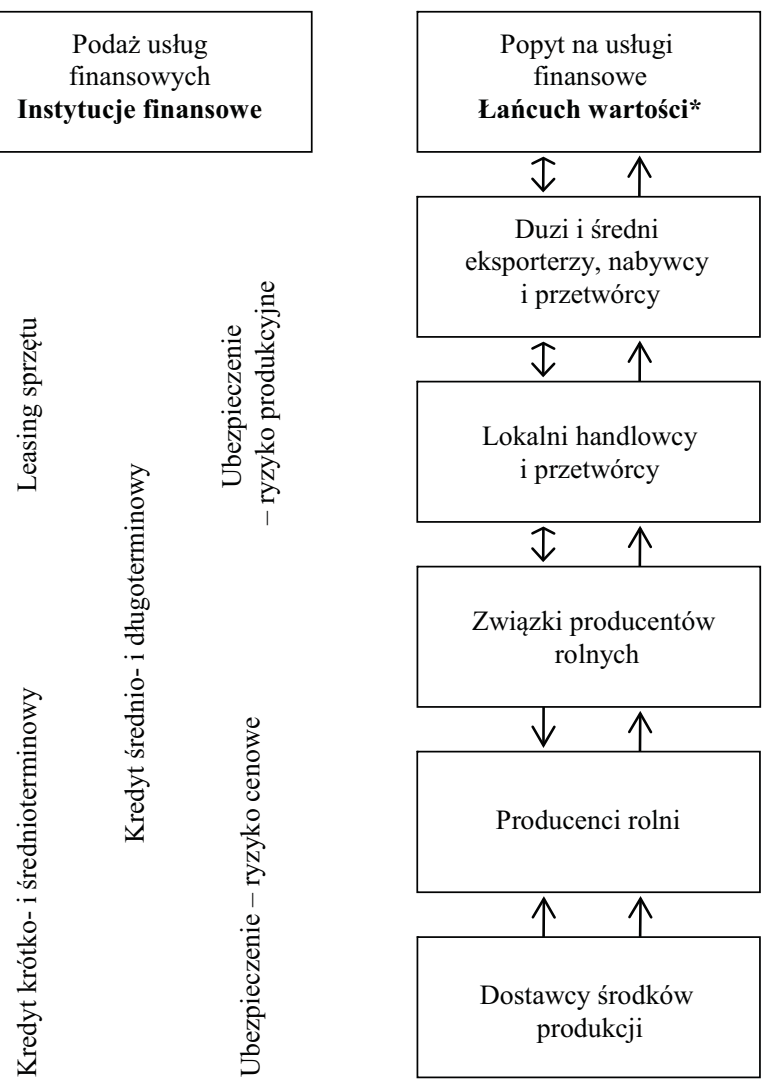

Podaż usług finansowych

Lańcuch wartości

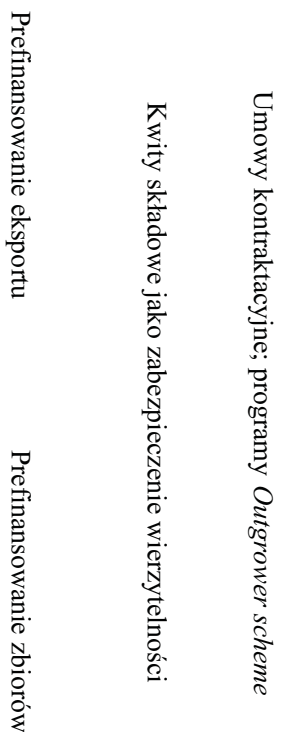

* Strzałki oznaczają przepływy gotówkowe w łańcuchu wartości.

Źródło: opracowanie własne na podstawie: A. Zawojska, op. cit., s. 96.

Tabela 2. Instrumenty finansowania łańcucha wartości

\begin{tabular}{|l|l|}
\hline \multicolumn{1}{|c|}{$\begin{array}{c}\text { Kategoria instrumentów } \\
\text { finansowych }\end{array}$} & \multicolumn{1}{c|}{ Instrumenty finansowe } \\
\hline $\begin{array}{l}\text { Finansowanie produktu } \\
\text { (ang. product financing) }\end{array}$ & $\begin{array}{l}\text { - kredyt handlowy } \\
\text { - kredyt wewnętrznego dostawcy (ang. input supplier credit) } \\
\text { - kredyt firmy marketingowej (ang. marketing company credit) } \\
\text { - finansowanie wiodącego przedsiębiorstwa (ang. lead firm } \\
\text { financing) }\end{array}$ \\
\hline $\begin{array}{l}\text { Finansowanie wierzytelności } \\
\text { (ang. receivables financing) }\end{array}$ & $\begin{array}{l}\text { - finansowanie należności handlowych (ang. trade receivab- } \\
\text { - les finance) }\end{array}$ \\
\hline $\begin{array}{l}\text { - faktoring } \\
\text { fabezpieczenie majątku rze- } \\
\text { czowego (ang. physical assets } \\
\text { collateralization) }\end{array}$ & $\begin{array}{l}\text { - kwity magazynowe (ang. warehouse receipts) } \\
\text { - transakcja warunkowego odkupu (ang. repurchase } \\
\text { agreements - repo) }\end{array}$ \\
\hline
\end{tabular}




\begin{tabular}{|l|l|}
\hline $\begin{array}{l}\text { Produkty ograniczające ryzyko } \\
\text { (ang. risk mitigation products) }\end{array}$ & $\begin{array}{l}\text { - ubezpieczenia (upraw i pogodowe) } \\
\text { - forward }\end{array}$ \\
\hline $\begin{array}{l}\text { Ulepszenia finansowe } \\
\text { (ang. financial enhancement) }\end{array}$ & $\begin{array}{l}\text { - sekurytyzacja } \\
\text { - gwarancje bankowe } \\
\text { - finansowanie joint venture }\end{array}$ \\
\hline
\end{tabular}

Źródło: opracowanie własne na podstawie: C. Miller, L. Jones, op. cit., s. 56-57.

\section{Instrumenty finansowania łańcucha wartości}

\section{Finansowanie produktu}

Do instrumentów finansowania produktu (ang. product financing) należą przede wszystkim popularne wśród rolników kredyty, bez których rozpoczęcie działalności innowacyjnej jest często niemożliwe. Dzięki silnym powiązaniom podmiotów w łańcuchu wartości oraz dostępności nowoczesnej technologii i komunikacji instrumenty te są ulepszane i dostosowywane do potrzeb łańcucha wartości. Należy do nich m.in. kredyt handlowy (ang. trade credit), polegający na wypłaceniu producentowi rolnemu przez handlowca lub przetwórcę środków, które są zwracane, zwykle w postaci produktów rolnych, w czasie zbiorów (Soundarrajan, Vivek 2015, s. 33). Taka forma finansowania gwarantuje handlowcom pozyskanie produktów w późniejszym terminie, a rolnikom zapewnia środki pieniężne jeszcze przed zbiorem płodów rolnych. Inną formą finansowania w tej kategorii jest kredyt wewnętrznego dostawcy (ang. input supplier credit), który funkcjonuje głównie na niższych stopniach łańcucha wartości (por. Rysunek 1). Polega on na dostarczeniu rolnikom, lub innym uczestnikom łańcucha, środków produkcji rolnej, np. nawozów, nasion, środków ochrony roślin, z odroczonym terminem płatności. Koszt kredytu jest zazwyczaj doliczony do ceny produktów (Miller i Jones 2010, s. 56). Na podobnych zasadach funkcjonuje kredyt firmy marketingowej (ang. marketing company credit). Finansowanie wiodącego przedsiębiorstwa (ang. lead firm financing) charakteryzuje się natomiast szerszym zakresem usług, gdyż - poza zapewnianiem bezpośredniego finansowania podmiotom $\mathrm{z}$ łańcucha wartości, w tym rolnikom - gwarantuje umowy sprzedaży, umożliwia dostęp do finansowania przez instytucje zewnętrzne, a także oferuje pomoc techniczną i dostęp do rynku (Soundarrajan, Vivek 2015, s. 33). Wydaje się, że forma kredytowania $\mathrm{w}$ finansowaniu łańcucha wartości jest odpowiednia na etapie wdrażania innowacji produktowych $\mathrm{w}$ gospodarstwie rolnym, kiedy niezbędne jest pozyskanie środków produkcji rolnej, m.in. nawozów, środków ochrony roślin czy pasz dla zwierząt. 


\section{Finansowanie wierzytelności}

Finansowanie wierzytelności (ang. receivables financing) to ogólna forma finansowania dokonywanego pod zabezpieczenie wierzytelnościami i umowami sprzedaży. W tym przypadku pożyczki udziela się zwykle w formie pieniężnej lub niepieniężnej, w postaci produktów rolnych, a jej zabezpieczeniem jest cesja tych wierzytelności. Ich spłata przechodzi z wpływów ze sprzedaży bezpośrednio do pożyczkodawcy. Finansowanie wierzytelności jest często dostosowane do indywidualnych potrzeb kontrahentów, co pozwala przyspieszyć przepływy gotówkowe i zmniejszyć ryzyko (Miller i Jones 2010, s. 67). Do tej grupy instrumentów Miller i Jones zaliczyli znane wśród przedsiębiorstw faktoring i forfaiting, a także finansowanie należności handlowych (ang. trade receivables finance). To ostatnie polega na udostępnieniu kapitału obrotowego podmiotom związanym z rolnictwem - dostawcom, przetwórcom, eksporterom - przez banki lub inne instytucje finansowe (Rysunek 3). Transakcja następuje w wyniku wykupu należności finansowych albo akceptacji potwierdzenia zlecenia dla producentów.

Rysunek 2. Schemat finansowania należności handlowych

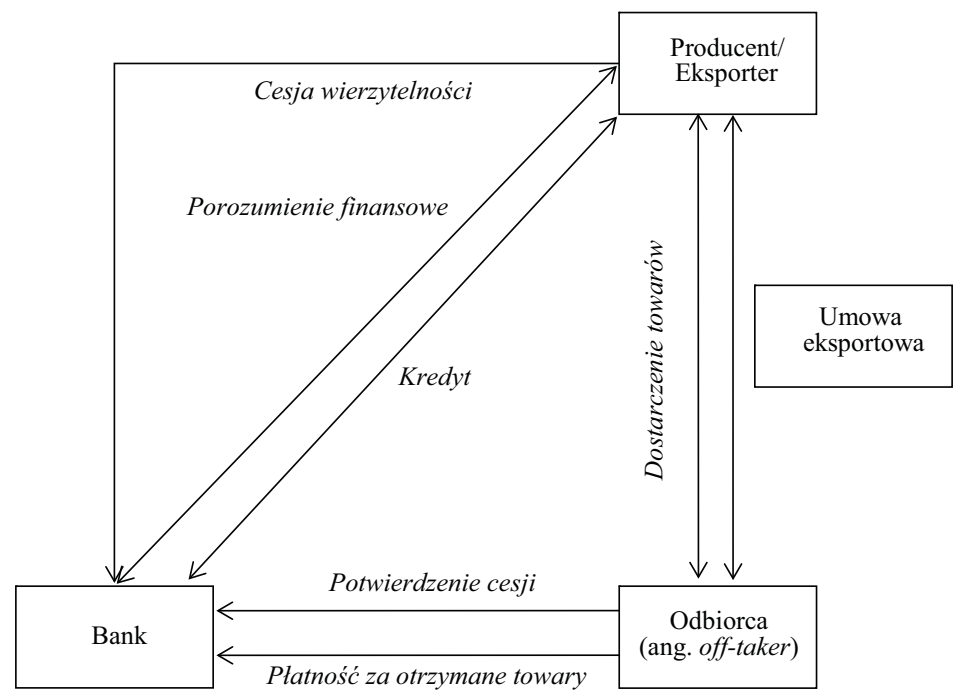

Źródło: Winn M., Miller C., Gegenbauer I. (2009), The use of structured finance instruments in agriculture in ECA countries, „AGSF Working Document”, 26, FAO, Rzym 2009, s. 18.

\section{Finansowanie majątku rzeczowego}

Kluczową koncepcją w przypadku VCF jest wykorzystanie łańcucha i jego produktów w celu zabezpieczenia transakcji finansowych. Finansowe zabezpieczenie towarami lub ruchomymi aktywami można często zastosować nawet 
wtedy, gdy powiązania w łańcuchu wartości są słabe lub fragmentaryczne. Jednak znacznie łatwiej jest je pozyskać w przypadku nowoczesnych łańcuchów wartości z silnymi powiązaniami, bezpiecznymi rynkami i powszechnie akceptowanymi standardami. Takie cechy są często spotykane w zintegrowanych modelach procesu innowacyjnego, budujących powiązania między gospodarstwem a dostawcami i nabywcami innowacyjnych produktów już na wczesnym etapie prac. Model przewiduje integrację w zespołach działalności $\mathrm{B}+\mathrm{R}$ oraz powiązania $\mathrm{z}$ działalnością produkcyjną procesu innowacyjnego. Silne i trwałe relacje umożliwiają uzyskanie dodatkowego, tańszego finansowania dzięki redukcji konwencjonalnych źródeł zabezpieczenia (Miller i Jones 2010, s. 72). Jednym z instrumentów zabezpieczenia majątku rzeczowego są kwity magazynowe (ang. warehouse receipts), wydawane deponentom towarów trwałych przez atestowane magazyny. Kwity umożliwiają instytucjom finansowym wykorzystywanie zdeponowanych zapasów do zabezpieczania transakcji finansowych (Fries i Akin 2004, s. 8). Przykład funkcjonowania systemu kwitów magazynowych w indyjskim banku HDFC przedstawiono na Rysunku 3.

Rysunek 3. System kwitów magazynowych banku HDFC

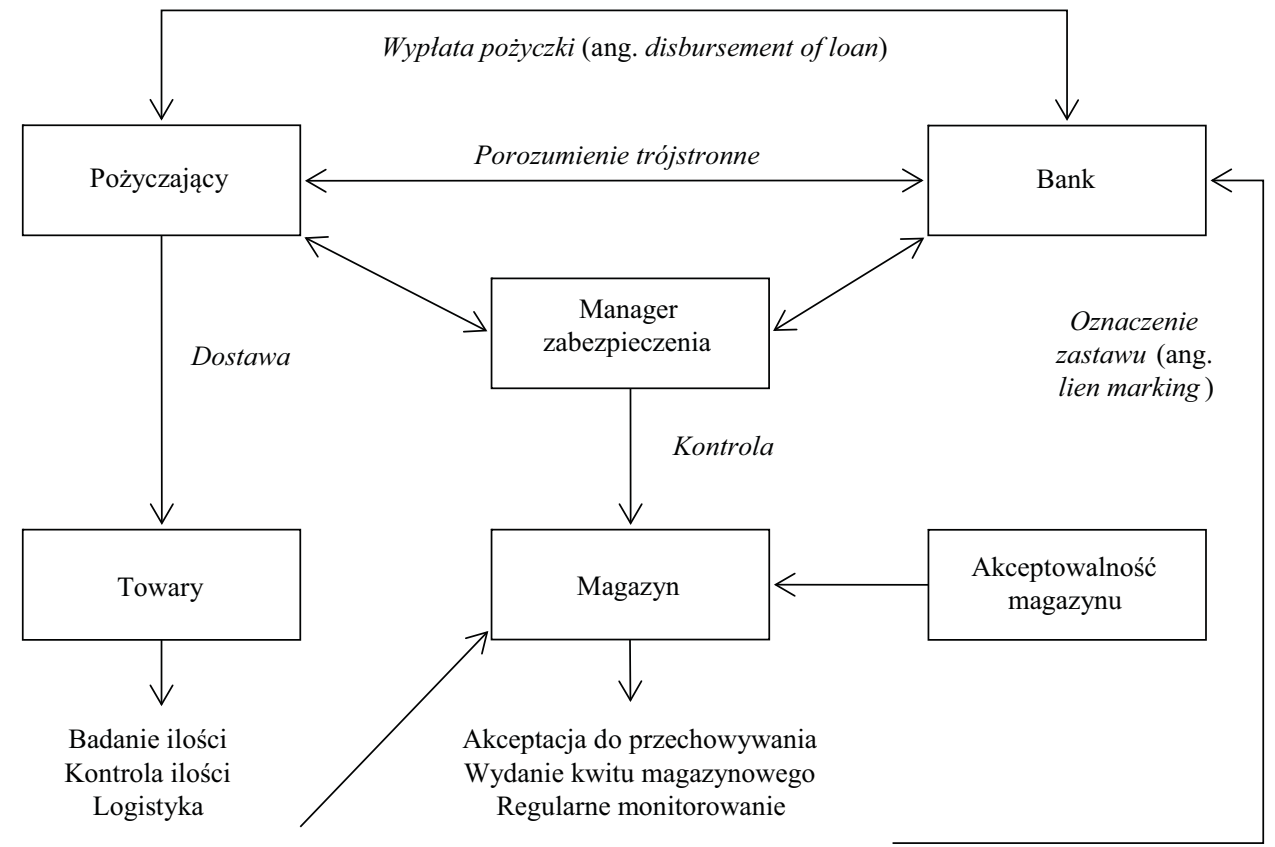

Źródło: Ananthakrishnan P.V. (2007), Structured finance through collateral management, presentation at the Asia International Conference, [w:] C. Miller, L. Jones, Agricultural value chain finance. Tools and lessons, FAO, Rzym 2010, s. 73. 
W ramach zabezpieczania majątku rzeczowego dostępne są również transakcje warunkowego odkupu, nazywane repo (ang. repurchase agreements - repo), coraz częściej wykorzystywane przez handlowców i przetwórców w łańcuchu wartości. Repo polega na sprzedaży towaru stronie trzeciej za zgodą sprzedawcy, który odkupi produkt po upływie określonego czasu. Towar będący w posiadaniu osoby trzeciej jest zwykle przechowywany w atestowanym magazynie. Dla sprzedawcy repo jest zwykle korzystniejsze od kredytu bankowego, a w przypadku instytucji finansowej fakt, że klient nie jest właścicielem zabezpieczonego składnika aktywów, ułatwia jego zbycie w przypadku braku płatności. Umowy $\mathrm{z}$ warunkowym odkupem jako innowacyjny instrument finansowania eksportu produktów rolnych są coraz częściej akceptowane przez ekspertów tego sektora.

\section{Produkty ograniczające ryzyko}

Oprócz finansowania łańcuch wartości umożliwia również ograniczenie ryzyka produkcyjnego, cenowego i kredytowego - dzięki korzystaniu z zabezpieczonych rynków, dostępności środków produkcji, technologii i usług rolniczych oraz lepszemu rozumieniu klientów instytucji finansowych. Finansowanie łańcucha wartości obejmuje wiele instrumentów opracowanych w celu efektywniejszego zarządzania zarówno ryzykiem systemowym, jak i indywidualnym. Instrumenty ograniczania ryzyka są istotne, ponieważ jest ono jednym z podstawowych utrudnień we wdrażaniu innowacji w gospodarstwach rolnych. Wprowadzenie na polski rynek rolny efektywnych instrumentów mających na celu minimalizację ryzyka zwiększyłoby poziom bezpieczeństwa nie tylko transakcji finansowych, ale przede wszystkim produkcji, tak silnie uzależnionej od warunków pogodowych. Miller i Jones do grupy produktów ograniczających ryzyko (ang. risk mitigation products) zaliczają ubezpieczenia (upraw i pogodowe), forward i futures.

\section{Ulepszenia finansowe}

Ostatnią grupą instrumentów finansowania łańcucha wartości są ulepszenia finansowe (ang. financial enhancements), które dotyczą szerokiego zakresu często skomplikowanych mechanizmów finansowania mających na celu zmniejszenie ryzyka. Obejmują one m.in. sekurytyzację, gwarancje bankowe oraz finansowanie joint venture. Sekurytyzacja nie była dotychczas szeroko stosowana w rolnictwie ze względu na wysokie ryzyko kredytów rolnych i koszt ustanowienia aktywów sekurytyzacyjnych, które zwykle sprawiają, że jest ona odpowiednia wyłącznie w przypadku dużych transakcji. Inną poważną przeszkodą, jeśli chodzi o wykorzystanie sekurytyzacji w rolnictwie, są trudności w uzyskaniu wiarygodnego ratingu kredytowego dla działalności rolniczej (Winn i Miller 2009, s. 29). Podobne wątpliwości może budzić finansowanie joint venture - chociaż 
nawiązanie współpracy z partnerem prywatnym i/lub publicznym mogłoby zwiększyć inwestycje w sektorze rolnym (Miller i Jones 2010, s. 93), to sektor ten może mieć awersję do tego rodzaju przedsięwzięć ze względu na konieczność współdzielenia nie tylko ryzyka, lecz również zysków z inwestycji (Soundarrajan, Vivek 2015, s. 32).

Gwarancje bankowe zapewniają zabezpieczenie rolnikom, którzy nie mają zdolności kredytowej wymaganej przez bank, i są rozwiązaniem dostępnym dla większości podmiotów rolniczego łańcucha wartości. W przypadku niewykonania zobowiązania gwarant zobowiązuje się do spłaty pożyczki w wysokości udzielonej gwarancji (Holle 2017).

\section{Podsumowanie}

Wymienione instrumenty mogą być stosowane oddzielnie, jednak efektywniejszy jest model finansowania złożony z kilku instrumentów dostosowanych do struktury sektora rolnego. W przypadku procesu innowacyjnego doskonałym rozwiązaniem może być zbudowanie modelu finansowania z poszczególnych elementów VCF, w tym instrumentów ograniczania ryzyka. Należy jednak pamiętać, że nie każdy instrument omówiony w tym artykule będzie mógł zostać wykorzystany w konkretnym łańcuchu wartości w rolnictwie (Miller 2011, s. 12). Nie jest zatem możliwe dopasowanie wszystkich instrumentów do prowadzonej w gospodarstwie działalności innowacyjnej. Przykładowo faktoring jest sprawdzonym rozwiązaniem często wykorzystywanym do finansowania wierzytelności w handlu i produkcji, jednak w rolnictwie nadal jest nową, a często nawet nieznaną formą wsparcia.

Należy podkreślić, że VCF nie polega wyłącznie na zaopatrywaniu łańcucha wartości w środki pieniężne. Instytucje finansowe angażują się w łańcuch wartości, by stał się on bardziej wydajny i konkurencyjny. Finansowanie łańcucha wartości to celowa interwencja, która restrukturyzuje go i reorganizuje, powodując istotne zmiany w przepływie gotówkowym i informacyjnym w dostarczanych do łańcucha usługach, a czasami nawet w samym przepływie produktu (KIT i IIRR 2010, s. 33).

Przedstawione w artykule wyniki badań jasno określają preferencje finansowe polskich rolników. Niemal 100\% respondentów wykorzystuje środki własne, a około $30 \%$ korzysta $\mathrm{z}$ dostępnych alternatywnych źródeł finansowania, takich jak leasing czy finansowanie fabryczne. Kolejny wniosek płynący z badań dotyczy wykorzystania w rolnictwie nowego modelu finansowego - wydaje się to mało prawdopodobne, ponieważ tradycja i przyzwyczajenia polskich rolników mogą być zbyt poważną przeszkodą w uruchomieniu alternatywnego kapitału. Polscy rolnicy obawiają się negatywnych decyzji finansowania ze względu na ryzyko 
w rolnictwie, biurokrację czy sezonowość produkcji, skupiają się zatem na podstawowych instrumentach, z których korzystają od lat. Model VCF jest stworzony dla rolnictwa i uwzględnia wszystkie przeszkody wskazywane przez rolników w kwestionariuszu. Jest elastyczny i można go dostosować do warunków gospodarczych danego kraju, wykorzystując jednocześnie znane instrumenty finansowe. Zdaniem autorki zaprezentowany w artykule model finansowania mógłby się sprawdzić jako forma finansowania działalności polskich gospodarstw rolnych, oczywiście pod pewnymi warunkami. Jego dostosowanie może się jednak okazać czaso- i kosztochłonne, a tymczasem rolnicy byliby skłonni zaakceptować tylko taki model, który funkcjonowałby na prostych zasadach, z minimalnym udziałem biurokracji, i zapewniał szybki przepływ gotówki.

Należy podkreślić, że zastosowanie modelu VCF jest jedynie sugestią, jeśli chodzi o dalszy rozwój oferty finansowania sektora rolnego. Autorka rozważa poświęcenie dalszych badań analizie efektywności struktury kapitałowej podmiotów rolnych przedstawiającej model finansowania z elementami VCF.

\section{Bibliografia}

Ananthakrishnan P.V. (2010), Structured finance through collateral management [w:] C. Miller, L. Jones, Agricultural value chain finance. Tools and lessons, FAO, Rzym.

Felczak T. (2015), Źródła finansowania działalności indywidualnych gospodarstw rolniczych $w$ opinii zarzadzajacych, Zeszyty Naukowe Uniwersytetu Szczecińskiego, „Finanse, Rynki Finansowe, Ubezpieczenia”, 2/74(855).

Fries R., Akin B. (2004), Value Chains and their Significance for Addressing the Rural Finance Challenge, „microREPORT”, 20, USAID, Waszyngton.

G20 Global Partnership for Financial Inclusion - GPFI (2015), New Trends in Agricultural Finance. Synthesis Report, SME Finance Sub-Group.

Góral J. (2016), Instrumenty wspierania gospodarstw rolniczych w Polsce, „Marketing i Zarządzanie", 2(43).

Holle N., (2017) Agricultural Export Financing Tools, Agriculture Finance Support Facility and World Bank Group, Working Paper, http://www.agrifinfacility.org (data dostępu: 20.08.2018).

Horbowiec B., Kalisiak A., Zawojska A. (2016), Źródła finansowania produkcji inwestycji $w$ indywidualnych gospodarstwach rolnych $w$ Polsce, Zeszyty Naukowe SGGW, „Ekonomika i Organizacja Gospodarki Żywnościowej”, 116.

Kałuża H., Ginter A. (2014), Innowacje w gospodarstwach rolniczych młodych rolników, Prace Naukowe Uniwersytetu Ekonomicznego we Wrocławiu, „Agrobiznes 2014. Rozwój agrobiznesu w okresie 10 lat przynależności Polski do Unii Europejskiej”, 361. 
Kałuża H., Krakowska M. (2013), Źródła finansowania innowacji w gospodarstwach rodzinnych w powiecie siedleckim, „Folia Pomeranae Universitatis Technologiae Stetinensis. Oeconomica", 70.

Kałuża H., Rytel M. (2010), Innowacyjność w świetle studium przypadku gospodarstw rolniczych z gminy Mokobody, „Roczniki Naukowe Stowarzyszenia Ekonomistów Rolnictwa i Agrobiznesu", XII, 5.

Kata R. (2011), Interwencjonizm kredytowy w rolnictwie a problem dostepu rolników do kredytu bankowego, „Roczniki Nauk Rolniczych”, seria G, 98(2).

Kiełbasa B., Puchała J. (2015), Innowacyjność młodych rolników i ich postawy wobec zmian na przyktadzie gospodarstw rolnych położonych $w$ regionie rozdrobnionego rolnictwa, „Roczniki Naukowe SERiA”, XVII, 1.

KIT and IIRR (2010), Value chain finance: Beyond microfinance for rural entrepreneurs, Royal Tropical Institute, Amsterdam; International Institute of Rural Reconstruction, Nairobi.

Marcysiak A., Marcysiak A. (2009), Źródła finansowania działalności bieżacej $i$ inwestycyjnej gospodarstw rolnych, ,Zeszyty Naukowe SGGW w Warszawie. Problemy Rolnictwa Światowego", 9(24).

Miller C. (2011), Agriculture value chain finance strategy and design, FAO on the UN. Miller C., Jones L. (2010), Agricultural value chain finance. Tools and lessons, FAO, Rzym.

MRiRW, Ptatności bezpośrednie w ramach Wspólnej Polityki Rolnej UE - historia, http://www.arimr.gov.pl (data dostępu: 28.02.2020).

Niezgoda D. (2009), Uwarunkowania rentowności gospodarstw rolnych zróżnicowanych pod względem wielkości ekonomicznej, „Roczniki Nauk Rolniczych", seria G, 96(4).

Soundarrajan P., Vivek N. (2015), A study on the agricultural value chain financing in India, ,Agricultural Economics”, 61(1).

Średzińska J. (2017), Czynniki kształtujace dochody gospodarstw rolnych Unii Europejskiej wedlug klas wielkości ekonomicznej, „Prace Naukowe Uniwersytetu Ekonomicznego we Wrocławiu", 477.

Węcławski J. (2010), Banki spółdzielcze w konkurencyjnym otoczeniu, „Annales Universitatis Mariae Curie-Skłodowska. Sectio H. Oeconomia", 44(1).

Winn M., Miller C., Gegenbauer I. (2009), The use of structured finance instruments in agriculture in ECA countries, „AGSF Working Document”, 26, FAO, Rzym.

Zawadzka D., Szafraniec-Siluta E. (2014), Leasing jako źródło finansowania inwestycji gospodarstw rolnych na przykladzie regionu Pomorza Środkowego, „Roczniki Naukowe SERiA”, 16(3)

Zawojska A. (2008), Uwarunkowania i kanaty finansowania rolnictwa w Polsce, Zeszyty Naukowe SGGW, „Ekonomika i Organizacja Gospodarki Żywnościowej”, 65. 


\section{Streszczenie}

Celem artykułu jest zaproponowanie alternatywnego finansowania innowacyjnej działalności gospodarstw rolnych w oparciu o modele stosowane w państwach spoza UE. Na podstawie wywiadów kwestionariuszowych przeprowadzonych w 2018 r. w województwie łódzkim na grupie 150 gospodarstw rolnych prowadzących księgi rachunkowe w ramach systemu FADN oraz przeglądu literatury przedmiotu określono preferencje polskich rolników co do źródeł finansowania innowacyjnej działalności gospodarstw. Należą do nich przede wszystkim: środki własne (dochody), kredyty bankowe oraz fundusze europejskie. Jako alternatywne finansowanie podmiotów rolnych autorka proponuje value chain financing (VCF), system powszechnie stosowany w krajach Ameryki Łacińskiej, Azji, Afryce i częściowo w Europie. W artykule zaprezentowano następujące kategorie instrumentów finansowych będących składowymi VCF: finansowanie produktu, finansowanie wierzytelności, zabezpieczenie majątku rzeczowego, produkty ograniczające ryzyko i ulepszenia finansowe. W podsumowaniu zawarto sugestie dotyczące zastosowania modelu VCF w polskich realiach oraz przesłanki dalszych badań.

Słowa kluczowe: gospodarstwo rolne, działalność innowacyjna, finansowanie łańcucha wartości, fundusze europejskie, dochody rolnicze

\section{Summary}

\section{An alternative model of financing in agriculture on the example of foreign models}

The aim of the article is to present proposals for alternative financing of farms based on models used in countries outside the EU. At the outset, the preferences of Polish farmers in the area of financing innovative activities were diagnosed based on questionnaire interviews conducted in 2018 in the Łódź Voivodeship on a group of 150 farms that keep accounting books under the Farm Accountancy Data Network (FADN) system. Based on the interviews (and a review of the literature on the subject), three basic sources of financing the innovative activity of farms were identified: own funds (income), bank loans, and European funds. As part of alternative financing of agricultural entities, the author offers value chain financing (VCF), commonly used in Latin America, Asia, and Africa, and partly in Europe. The article presents the following categories of financial instruments that 
are components of the VCF: product financing, receivables financing, physical assets collateralization, risk mitigation products, and financial enhancement. The summary contains suggestions for the application of the VCF model in Poland and premises for further research.

Keywords: farm, innovation activity, value chain financing, European funds, agricultural income

JEL: Q13, Q16 